Journal of Reproduction and Development, Vol. 39, No. 4, 1993

\title{
Isolation and Partial Characterization of a Bovine Amniotic Fluid Protein
}

\author{
Hiroharu MATSUSHITA, Kenji TUCHIHASHI, \\ Shuichi ASANO, Toshiho NISHITA, \\ Manabu YAMADA ${ }^{1)}$, and Hirohumi ANDO' \\ Laboratory of Veterinary Physiology I, School \\ of Veterinary Medicine, Azabu University, \\ 1-17-71 Fuchinobe, Sagamihara, Kanagawa 229, \\ 1) Laboratory of Animal Physiology, School of \\ Bioresources, Hiroshima Prefectural University, \\ 562 Dobashiyama, Nanatsuka, Shohara, Hiroshima 727, and \\ 2) Laboratory of Clinical Research, School of \\ Medicine, Teikyo University, 2-11-1 Kaga, \\ Itabashi-ku, Tokyo 173, Japan
}

\begin{abstract}
An bovine, amniotic-fluid protein, (bAP), was purified from amniotic fluid by gel filtration, anion exchange chromatography and isoelectric focusing. The isolation was monitored by a double immunodiffusion with an antiserum raised against amniotic fluid antigens and absorbed with maternal and fetal sera. The molecular weight of an amniotic fluid protein isolated was estimated as 60,000 by SDS-PAGE, and the isoelectric point by isoelectric focusing was 3.4-3.8.
\end{abstract}

Key words: Bovine, Amniotic fluid, Pregnancy-associated protein.

(J. Reprod. Dev. 39: 275-279, 1993)

$\mathbf{T}$ he soluble proteins in amniotic fluid are originated predominantly in maternal serum, and in small proportion in fetal serum and the placental membrane [1]. In common with proteins of fetal origin, the major species of proteins in the amniotic fluid are apparently synthesized by the endometrium/decidua [2]. Secretory proteins by the fetus has recently been investigated. Fay et al. [3] carried out immunoelectrophoresis with antihuman amniotic fluid antibody and isolated 2 fetal antigens. A negative-affinity chromatography with anti-human serum antibody to the solid matrix, was introduced for the isolation of the proteins in amniotic fluid that do not derived from the maternal serum [4].

Only a few of non-maternal serum proteins have been isolated and characterized. In this study, an antiserum was raised against amniotic fluid antigens of cows and absorbed with maternal and fetal sera to detect a protein of amniotic origin. 


\section{Materials and Methods}

\section{Amniotic fluid and amniotic tissue}

Amniotic fluid was collected by amniocentasis from 4 cows at the last month of gestation. The collected samples were cleared of cells and other non-soluble materials by centrifugation $10,000 \times \mathrm{g}$ for $30 \mathrm{~min}$ at $4 \mathrm{C}$, stored at $-20 \mathrm{C}$, and used for immunization.

\section{Preparation of antisera}

Five male Japanese white rabbits received intradermal injections of $5 \mathrm{ml}$ of the amniotic fluid (containing $45 \mathrm{mg}$ protein) emulsified in an equal volume of Freund's complete adjuvant at 2 weeks intervals for 10 weeks. Each antiserum obtained 7 days after the 5th injection was incubated with equal volumes of both pregnant and fetal sera for $2 \mathrm{~h}$ at $37 \mathrm{C}$ and then overnight at $4 \mathrm{C}$, centrifuged at $10,000 \times \mathrm{g}$ for $30 \mathrm{~min}$ and stored. All the animals immunized produced antibodies against the amniotic fluid antigens. But the absorbed antisera from 3 of 5 animals failed to react with amniotic fluid proteins by immunodiffusion test. A double-diffusion test was carried out using 1.2\% agar in saline solution. Immunoelectrophoresis was performed in $1.2 \%$ agar in $0.06 \mathrm{M}$-barbital buffer ( $\mathrm{pH}$ 8.6).

\section{Separation of the amniotic fluid protein}

1) Ammonium sulfate precipitations: Amniotic fluid was fractionated by precipitation with ammonium sulfate between different concentration and saturation; 0-40\%-, 40-65\%-, 65-85\%-, 85-100\%saturation. Each fraction was dialyzed against $0.05 \mathrm{M}$ Tris-HCl buffer (pH 8.0). Dried ammonium sulfate crystals were slowly added to obtain $40 \%$-saturated solution. The samples were allowed to precipitate for $2 \mathrm{~h}$, and the supernatant was discarded after centrifugation. Additional ammonium sulfate was added to make $65 \%$-saturated solution, and the solution was stirred for $1 \mathrm{~h}$. After centrifugation, the precipitate was dissolved in $0.05 \mathrm{M}$ Tris- $\mathrm{HCl}$ buffer ( $\mathrm{pH} 8.0$ ), and extensively dialyzed against the same buffer. The solution was then centrifuged at $10,000 \times \mathrm{g}$ for $30 \mathrm{~min}$, and the precipitate was discarded.

2) Gel filtration and ion exchange chromatographies: The fraction isolated by $40-65 \%$ saturated ammonium sulfate was chromato- graphed on Sephadex G-200 (Pharmacia). The column was equilibrated and eluted with $0.05 \mathrm{M}$ Tri-HCl buffer ( $\mathrm{pH}$ 8.0). Six $\mathrm{ml}$ of the sample was loaded onto the column $(1.5 \times 70 \mathrm{~cm})$ and fractionated $5 \mathrm{ml}$ of each protein concentration was monitored by UV adsorption at $280 \mathrm{~nm}$. A bovine amniotic fluid protein (bAP) positive fractions were pooled and ultrafiltrated. The concentrated solution was chromatographed on DEAESephadex (Pharmacia A-25). The column $(2.2 \times$ $24.5 \mathrm{~cm}$ ) had previously been equilibrated with $0.05 \mathrm{M}$ Tris-HCl buffer ( $\mathrm{pH}$ 8.0). After unbound proteins were washed through, the column was eluted with a $0-1.0 \mathrm{M}-\mathrm{NaCl}$ gradient in $0.05 \mathrm{M}$ Tris-HCl buffer ( $\mathrm{pH}$ 8.0). The bAP-positive fractions were pooled, dialyzed against $0.05 \mathrm{M}$ phosphate buffer ( $\mathrm{pH} 8.0)$, and lyophilized.

3) Isoelectric focusing: The preparative electrofocusing was done on the column (LKB 8100-1) with sucrose gradient solution contained $2 \%$ ampholytes with an operating range of $\mathrm{pH} 2.5-6.0$ at $3 \mathrm{~W}$ and $4 \mathrm{C}$ for $24 \mathrm{~h}$. Protein concentrations were monitored at $280 \mathrm{~nm}$.

4) Polyacrylamide gel electrophoresis under non-denaturing conditions: Purified and concentrated samples from amniotic fluid were applied to a $7.5 \%$ polyacrylamide disc gel with buffer consisted of $0.05 \mathrm{M}$ Tris-HCl ( $\mathrm{pH} \mathrm{8.0)}$. After the samples ran into the gel at $2 \mathrm{~mA} /$ gel for $15 \mathrm{~min}$, the electrophoresis was developed for $2.5 \mathrm{~h}$ at 3 $\mathrm{mA} /$ gel. The gel was stained with coomassiebrilliant blue R-250/0.05\% in $10 \%$ acetic acid and $45 \%$ methanol.

5) SDS-polyacrylamide gel electrophoresis: For one dimensional SDS gradient gel electrophoresis, less than $50 \mu \mathrm{l}$ of each fractionated sample was mixed with an equal volume of buffer containing $\beta$-mercaptoethanol (10\%), SDS (10\%), glycerol $(20 \%)$, trizma (0.125 M, pH 6.8) and bromophenolblue $(0.002 \%)$. Samples were heated for $1 \mathrm{~min}$ at $100 \mathrm{C}$ and analyzed. Gels were stained for 30 min with coomassiebrilliant blue $\mathrm{R} 250 / 0.05 \%$ in $10 \%$ acetic acid $45 \%$ methanol. Gels were calibrated with the proteins of known molecular weight.

\section{Results}

Absorption of the bovine amniotic-fluid antiserum with maternal and fetal calf sera removed 
all but one band (Fig. 1) in the antisera generated in 2 of 5 rabbits. Immunoelectrophoresis using fetal serum and unabsorbed antiserum resulted in the formation of several precipitine bands, whereas no precipitine bands were visible when term pregnancy serum was tested against the absorbed antiserum (Fig. 2). When purified bovine amniotic fluid protein (bAP) was tested against the antisera on immunoelectrophoresis, one precipitine line was formed in the beta-region (Fig. 2). Although there is a wide variety of bAP concentrations among different samples of amniotic fluid, maximum concentrations were found during the term of pregnancy.

Amniotic fluid fractions of the $40-65 \%$ ammonium sulfate cut were pooled and subjected to gel chromatography. Fig. 3 shows the profile of eluted proteins from the Sephadex-G200 column. The fractions with the highest immunoreaction were pooled and analyzed by ion exchange chroma-

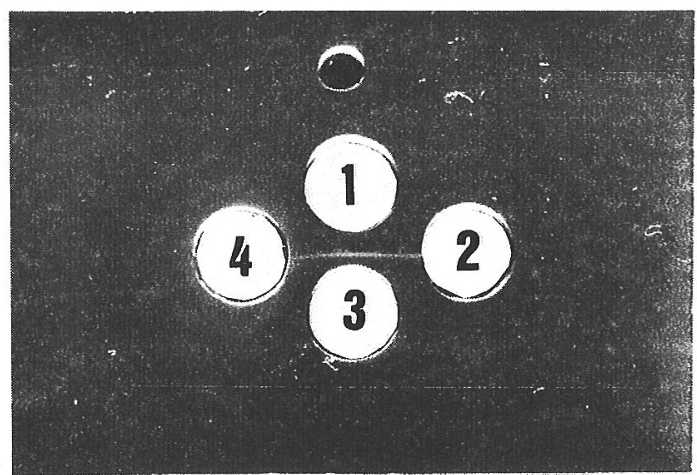

Fig. 1. Ouchterlony gel precipitin after diffusion of various body fluids against anti-bAP serum. 1 , bovine amniotic fluid of late pregnancy; 2 , bovine fetal serum of late pregnancy; 3 , antiserum to bovine amniotic fluid absorbed with both maternal and fetal sera; 4 , bovine maternal serum of late pregnancy.

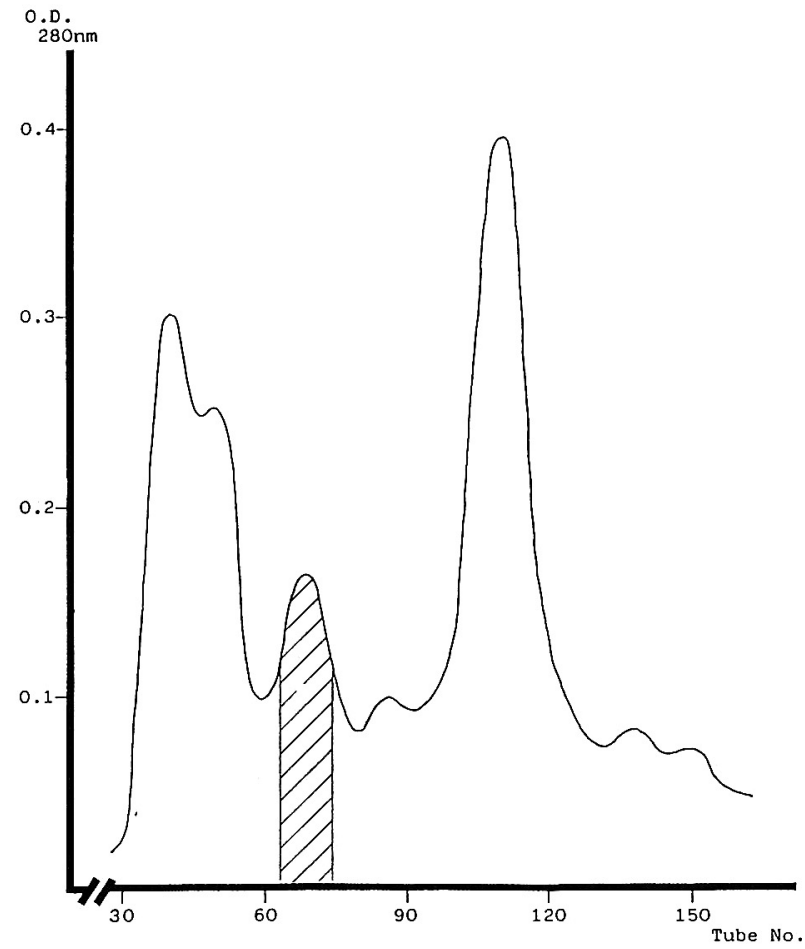

Fig. 3. Gel filtration of the bovine amniotic fluid precipitated at $40-65 \%$ ammonium sulfate on a column $(70 \times 1.5 \mathrm{~cm})$ of Sephadex G200 equilibrated with $0.05 \mathrm{M}$ Tris buffer at $\mathrm{pH} 8.0$, and containing $0.01 \mathrm{M} \mathrm{NaCl}$. The stippled area indicates immunoreactive fractions.

tography. The bAP was quantitated by DEAE column. It eluted at $\mathrm{NaCl}$ concentrations between $0.4 \mathrm{M}$ and $0.5 \mathrm{M}$ (Fig. 4). The bAP-containing fractions eluted from DEAE-Sephadex were pooled, dialyzed and then concentrated by ultrafiltration on a collodion bag. Final purification was achieved by isoelectric focusing. The fraction from the DEAE-Sephadex column was applied to the column chromatofocusing. A typical chromato-

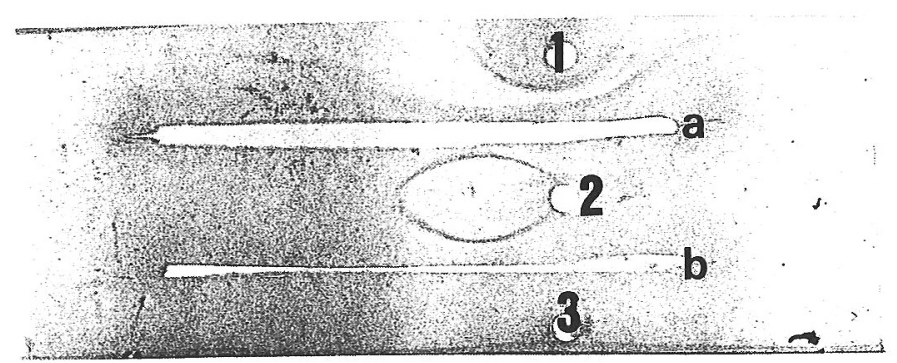

Fig. 2. Electrophoretic pattern at pH 8.6 of bovine amniotic fluid protein (bAP) with unabsorbed (a) and absorbed (b) rabbit antiamniotic fluid antisera. 1, serum from fetus at age of 9-month; 2 , purified bovine amniotic fluid protein; 3 , serum from a dam at term pregnancy. 


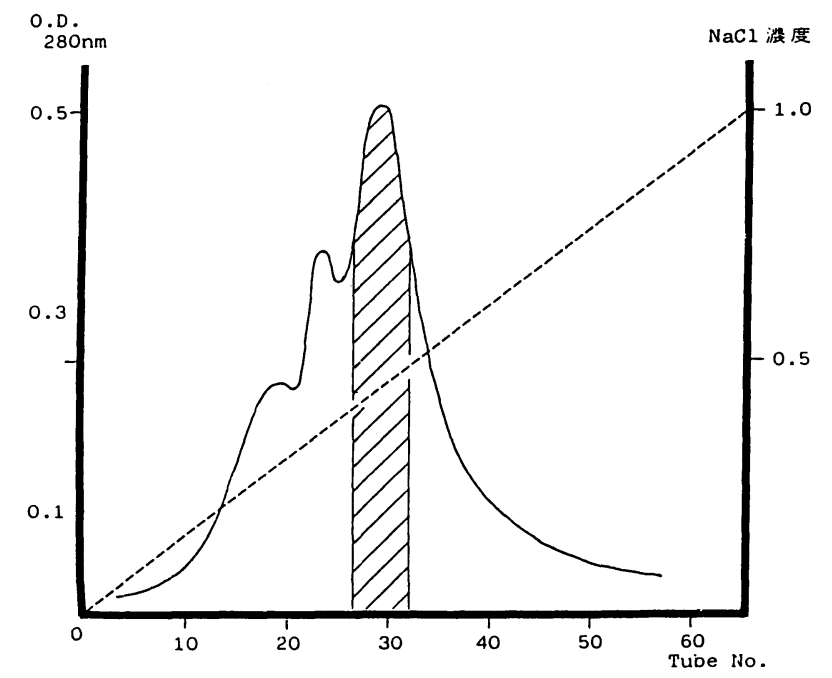

Fig. 4. An elution profile of bovine amniotic fluid protein from a DEAE-Sephadex column.

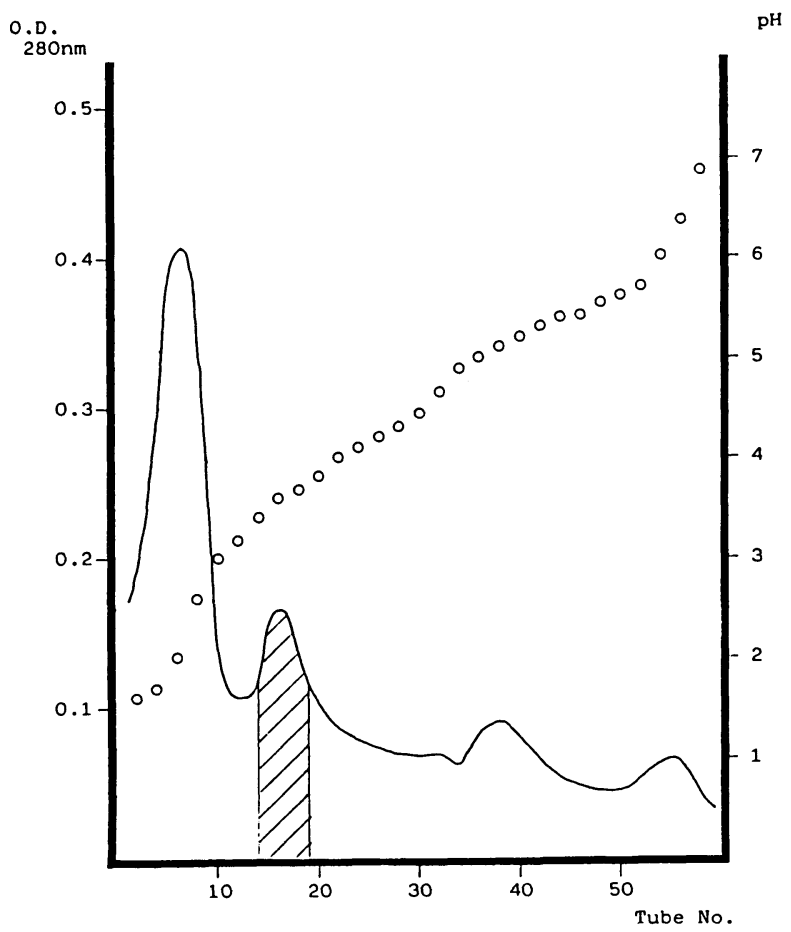

Fig. 5. Column isoelectric focusing of bovine amniotic fluid protein at $\mathrm{pH}$ 2.5-6.0 with a carrier of ampholytes.

gram profile is illustrated in Fig. 5. Under the condition of the gradient varying from $\mathrm{pH} 2.5$ to 6.0, bAP was eluted between $\mathrm{pH} 3.4$ and 3.8. The molecular weight of the separated bAP was estimated as 60,000 (Fig. 6).

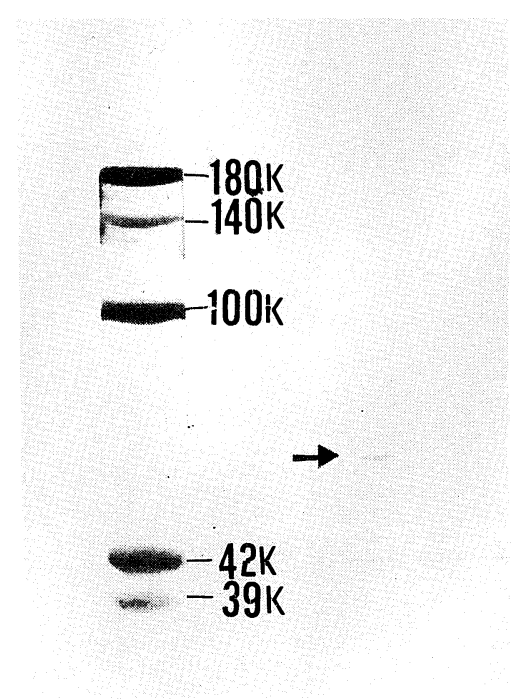

Fig. 6. Determination of the molecular weight of the bovine amniotic fluid protein by SDSpolyacrylamide gel electrophoresis. The left lane, marker proteins.

\section{Discussion}

Since a precipitation band formation was found even between the absorbed antisera and the amniotic fluid, we concluded that the antigen found in this study in the term amniotic fluid is not originated in the maternal serum. Amniotic fluid consists predominantly of maternal serum proteins, only a small proportion is derived from the fetus, the placenta, and the endometrium [9]. Several proteins of non-maternal serum origin are demonstrated in the human amniotic fluid by a two-dimensional gel electrophoresis [10], or by a negative immunoaffinity chromatography [4].

A pregnancy-specific protein was detected in the bovine uterus at early pregnancy [5]. Butler et al. [6] identified by serological procedures an apparently pregnancy-specific protein (PSPB) from bovine placental membranes. Beckers $e t$ al. [7] reported the isolation of pregnancy-associated proteins from bovine cotyledons. The molecular weight of this protein was estimated as 67,000 by SDS-PAGE, with pI ranging from 4.4 to 5.4 [8].

The bAP antigen in this study had beta-globulin 
mobility, the molecular weight by SDS-PAGE, was estimated to be 60,000 with a similar pI ranging from 3.4 to 3.8 as fetuin. However, the molecular weight of fetuin is reported as 48,400 [11].
The new protein of fetal origin will have potential value in prenatal diagnosis of fetal diseases.

\section{References}

1. Sutculiffe RG. Protein in human amniotic fluid. In: Sandle M (ed.), Amniotic Fluid and Its Clinical Significance. New York: Marcel Dekker, 1981; 129-167.

2. Seppälä M, Huhtala M-L, Julkunen M, Koistinen R, Rutanen E-M. Uterine proteins, nomenclature determined by biological action. Res Reprod 1987; 19(1): 2.

3. Fay TN, Jacobs, I, Teisner B, Poulsen O, Chapman MG, Stabile I, Bohn H, Westergaard JS, Grudzinskas JG. Two fetal antigens (FA-1 and FA-2) and endometrial proteins (PP12 and PP14) isolated from amniotic fluid; preliminary observations in fetal and maternal tissues. Eur J Obstet Gynecol Reprod Biol 1988; 29: 73-78.

4. Sørensen S. Isolation of amniotic fluid proteins of non-maternal serum origin by negative immunoaffinity chromatography. Clin Chim Acta 1991; 202: 199-210.

5. Laster DB. A pregnancy-specific protein in the bovine uterus. Biol Reprod 1977; 16: 682-690.
6. Butler JE, Hamilton WC, Sasser RG, Ruder GA, Hass GM, Williams RJ. Detection and partial characterization of two bovine pregnancy-specific proteins Biol Reprod 1982; 26: 925-933.

7. Beckers JF, Wouters-Ballman P, Ectors F. Isolation and radioimmunoassay of a bovine pregnancy specific protein. Theriogenology 1988; 29(suppl 1): 219.

8. Zoli AP, Beckers JF, Wouters-Ballman P, Closset J, Falmagne P, Ectors F. Purification and characterization of a bovine pregnancy-associated glycoprotein. Biol Reprod 1991; 45: 1-10.

9. Sutcliffe RG, Brock JH, Nicholson LVB, Dunn E. Fetal- and uterine specific antigens in human amniotic fluid. J Reprod Fert 1978; 54: 85-90.

10. Dermer GB, Edwards JJ. Detection of the major non serum derived proteins of body fluids by immunodelition and two-dimensional gel electrophoresis. Electrophoresis 1983; 4:212-218.

11. Spiro RG. Studies on fetuin, a glycoprotein of fetal serum. J Biol Chem 1960; 235: 2860-2869. 